症例

急性虫垂炎との鑑別が困難であった結核性腸間膜リンパ節炎の 1 例 細木病院外科

松下 耕太郎* 北 村 宗 生 蔁 原 作 治

急性腹症として発症する結核性腸間膜りンパ節炎は近年では稀であり，その診断に苦 慮することがある，われわれは，急性虫垂炎との鑑別が困難で, 開腹・生検により結核 性腸管膜リンパ節炎と診断された 1 例を経験したので報告する.

症例は28歳女性で, 主訴は発熱と右下腹部痛であった。腹部理学的所見より急性虫垂 炎を疑ったが, 血中白血球数が $6,400 / \mathrm{mm}^{3}$ であったため, 入院経過観察とした. 発熱と 腹痛が持続するため, 入院 2 日目に手術を施行した. 腹水を少量認め, 回盲部腸間膜に 鶏卵大から小指頭大のリンパ節の腫大を認めた。生検より結核性腸間膜リンパ節炎と診 断された。

腸間膜リンパ節炎の起炎菌はエルシニアが多く，結核菌は稀だと言われている．結核 の化学療法が確立された今日では，いかに早期に結核性だと診断し，治療を開始するか が問題であると考えられる。

索引用語：急性虫垂炎, 結核性腸間膜リンパ節炎

緒言

腹部結核は近年では稀な疾患であるが，その臨床像 は多彩である．急性腹症として発症し，虫垂炎との鑑 別が困難であった結核性腸間膜リンパ節炎の1例を経 験したので報告する。

\section{症例}

症例: 28 歳, 女性.

主訴：右下腹部痛, 発熱.

既往歴, 家族歴：特記すべきことなし.

現病歴: 平成 6 年 8 月 1 日, 右下腹部痛と $38^{\circ} \mathrm{C}$ 発 熱を認め近医を受診した。抗生物質を内服したが症状 の改善がなく,8月 3 日当院に紹介され入院となった。 下痢，便秘はみられなかった。

入院時現症：体格中等度. 体温 $37.5^{\circ} \mathrm{C}$. 脈拍 $66 /$ 分, 整. 血圧 $122 / 76 \mathrm{mmHg}$. 眼瞼結膜に貧血はなく, 眼球 結膜に黄疸はなかった。胸部の理学的所見に異常を認 めなかった。腹部は平坦であるが，右下腹部に安静時 疼痛を訴え, Mc Burney 点よりやや正中側を中心に強 い圧痛と筋性防御を認めた。 Blumberg sign (十), Rosenstein sign（士）であった。腫瘤は触知しなかっ た.また，表在リンパ節の腫脹は認めなかった。

1995年 1月31日受付 1995年10月12日採用

*現：香川医科大学第 1 外科
表 1 入院時検査所見

\begin{tabular}{cc|lc}
\hline $\begin{array}{cc}\text { 血液検查 } \\
\text { WBC }\end{array}$ & $6,400 / \mathrm{mm}^{3}$ & ALP & $88 \mathrm{IU} / l$ \\
$\mathrm{RBC}$ & $410 \times 10^{4} / \mathrm{mm}^{3}$ & $\mathrm{LDH}$ & $273 \mathrm{IU} / l$ \\
$\mathrm{Hb}$ & $11.7 \mathrm{~g} / \mathrm{dl}$ & $\mathrm{T}$. Bil & $0.3 \mathrm{mg} / \mathrm{dl}$ \\
$\mathrm{Ht}$ & $35.4 \%$ & $\mathrm{CPK}$ & $453 \mathrm{IU} / l$ \\
$\mathrm{PIt}$ & $17.8 \times 10^{4} / \mathrm{mm}^{3}$ & $\mathrm{BUN}$ & $8.4 \mathrm{mg} / \mathrm{dl}$ \\
$\mathrm{ESR}$ & $29 \mathrm{~mm} / \mathrm{hr}$ & $\mathrm{Cr}$ & $0.7 \mathrm{mg} / \mathrm{dl}$ \\
$\mathrm{CRP}$ & $3+$ & $\mathrm{Na}$ & $142 \mathrm{mEg} / l$ \\
$\mathrm{CRP}$ & $6.1 \mathrm{~g} / \mathrm{dl}$ & $\mathrm{K}$ & $4.6 \mathrm{mEq} / l$ \\
$\mathrm{TOT}$ & $22 \mathrm{IU} / l$ & $\mathrm{Cl}$ & $107 \mathrm{mEq} / l$ \\
$\mathrm{GPT}$ & $16 \mathrm{IU} / l$ & amylase & $326 \mathrm{IU} / l$ \\
尿検査 & & & \\
比重 & 1.030 & 潜血 & $(-)$ \\
タンパク & $( \pm)$ & 白血球 & $(-)$ \\
糖 & $(-)$ & アセトン & $(-)$ \\
\hline
\end{tabular}

入院時検查所見：白血球数は $6,400 / \mathrm{mm}^{3}$ と正常值 を示し，分画にも異常を認めなかった。しかし，CRP は $(3+)$ 陽性で, 血沈は 1 時間値 $29 \mathrm{~mm}$ と若干亢進し ていた. 血清総タンパク (TP)の軽度低下と,クレアチ ニンホスホキナーゼ (CPK) の若干高値以外に異常所 見を認めなかった(表 1 ). 胸部抢よび腹部単純 $X$ 線検 查には異常を認めなかった(図 1，2). 腹部超音波検 查では，肝蔵および胆霬には異常を認めなかった。下 腹部は腸管ガスのため,十分な情報が得られなかった。 


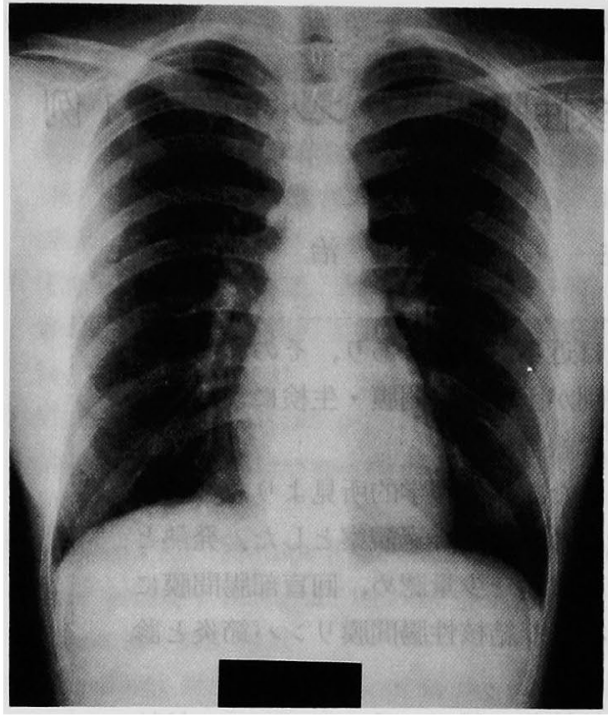

図 1 胸部正面 $\mathbf{X}$ 線写真：肺野に異常所見を認めない.

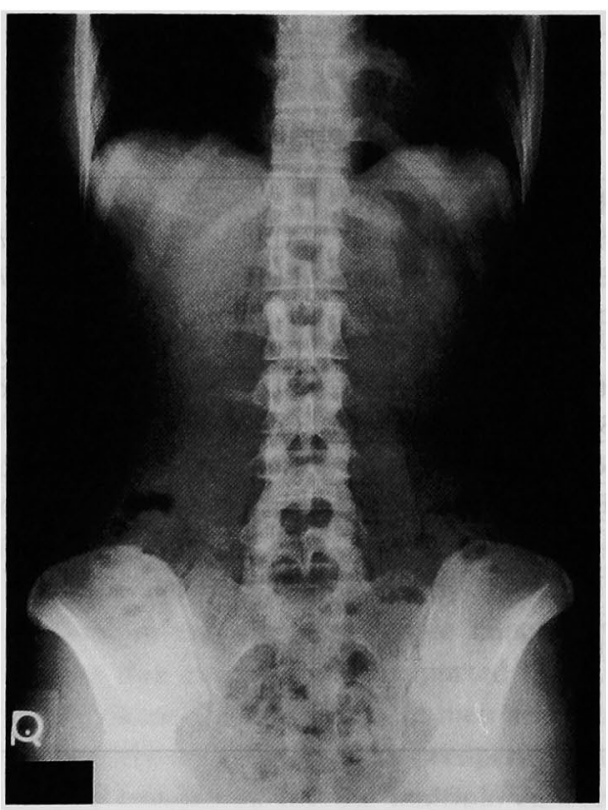

図 2 腹部正面 $\mathbf{X}$ 線写真：腹部に異常ガス像, 石灰化 像は認めなかった。

経過：腹部理学的所見から急性虫垂炎を最も疑った が, 白血球数が正常であり，保存的に経過観察とした。 翌日，絶飲食，抗生物質の経静脈的投与にもかかわら

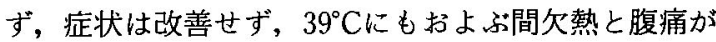
持続したため, 白血球数は $4,300 / \mathrm{mm}^{3}$ と正常であった が，急性虫垂炎の診断のもと平成 6 年 8 月 4 日手術を

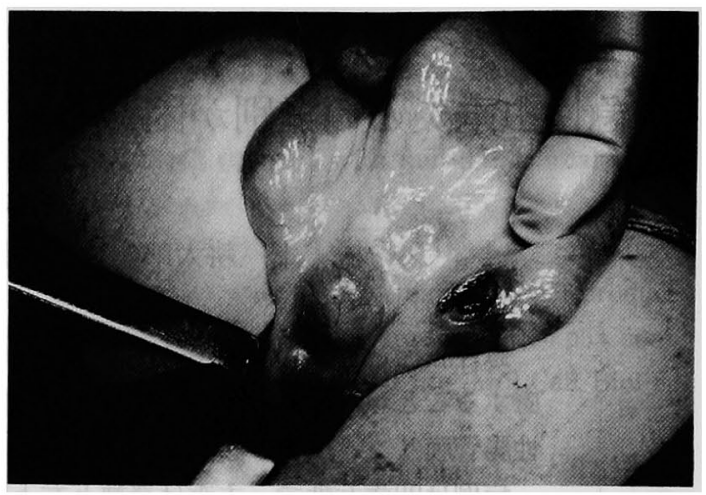

図 3 術中所見 : 回盲部腸間膜に鶏卵大から小指頭大 のリンパ節を多数認めた。

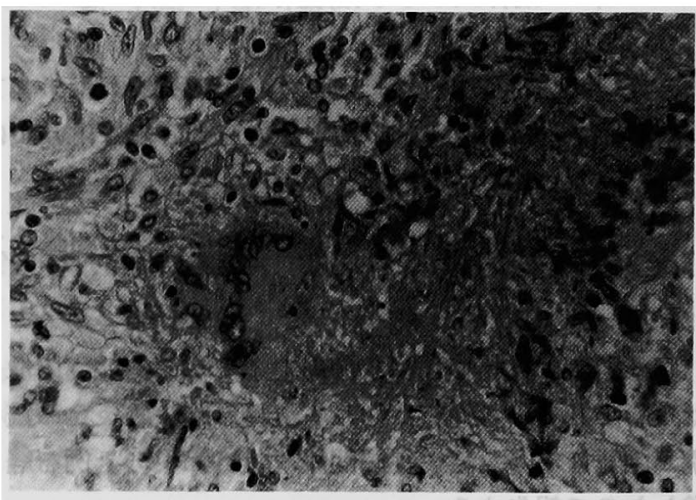

図 4 病理組織所見 $(\mathrm{HE}, \times 200)$ : 類上皮細胞, ラン グハンス型多核細胞などからなる比較的小型の肉芽 腫が形成され，その中心に乾酪壊死を認める。

施行した.

手術所見：傍腹直筋切開で開腹したところ, 回盲部 腸間膜に鷄卵大から小指頭大の類円形で表面平滑な軟 らかいリンパ節を多数認めた(図3). 虫垂は軽度の発 赤を認めたが, 明らかな炎症所見はなかった，獎液性 の腹水を少量認めたが, 回盲部の消化管に狭窄や獎膜 面の異常はなかった、リンパ節を 1 個生検し，虫垂の 切除を行い, ダグラス窝にドレーンを挿入し，手術を 終えた。

病理組織検査：回盲部リンパ節は類上皮細胞，ラン グハンス型巨細胞などからなる比較的小型の肉芽腫が 多数形成されており，その中心は壊死に陥り，結核性 リンパ節炎の所見であった(図 4 ). 虫垂は, 正常基本 構造はよく保たれており，部分的に粘膜内にとどまる 好中球浸潤を認めるが, 炎症は強くないとの所見を得 た. 
術後経過：術後も $39^{\circ} \mathrm{C}$ 以上の高熱が持続したが， $\gamma$ グロブリンを 2 日間使用して解熱僋向を示した。 しか し， $37^{\circ} \mathrm{C}$ 前後の微熱が持続した。一方，腹部理学的所 見は術後著明に改善し，術後 2 日目より経口捸取を開 始した。ドレーンからは少量の漿液性排液にとどまっ た。術後経過中，末梢血の白血球数は術前同樣に正常 範囲内であった，また，動脈血中およびドレーンから の腹水中には好気性および嫌気性細菌は認めなかっ た. 病理学的検査所見で結核性腸間膜リンパ節炎との 報告を受けた術後 9 日目に，内科に転科とし，isoniazid (INH) (200mg/day) rifanpicin (RFP) (450mg/ day)の化学療法を 2 カ月継続した. ツベルクリン反応 は発赤 $12 \times 8 \mathrm{~mm}$ ，硬結なく弱陽性であった。術後の注 腸検查では回盲部消化管の粘膜に腸結核を疑う所見は 認めなかった，術後 5 力月の現在，創部，全身状態に 異常なく, 就労している.

\section{考 察}

本症例は急性腹症として来院し, 腹部理学的所見か らは急性虫垂炎を疑いながらも，血液検查所見が腹部 所見と一致せず, 1 日の経過観察の後, 手術を施行し た。術後診断は腸間膜リンパ節炎, 病理診断は結核性 腸間膜リンパ節炎であった．腸間膜リンパ節炎は急性 虫垂炎との鑑別を要する疾患として重要であるが，起 炎菌はエルシニアによるものが多く"，結核性のもの は稀である。

結核自体は今日においても稀な疾患ではないが，腹 部結核すなわち腸結核，結核性腹膜炎，結核性腸問膜 リンパ節炎は結核の化学療法が確立するまでは, その 頻度は肺結核の重症度に相関していたと報告2されれて おり，今日，腹部結核の罹患率，死亡率はいずれも著 明に減少している2!．結核性腸間膜リンパ節炎の頻度 については, 1983年 Gilinsky ら3は125例の腹部結核の
中で 8 例あったと報告している。本邦では，われわれ が調べた限りでは，佐藤ら゙が1953年に報告したのに 始まり本症例を加えても，1953年より1994年まで16例 の報告があるのみで稀な疾患といえる.20歳代が 9 例, 30 歳代が 4 例, 40 歳代が 2 例とほとんどが若年者で, 男性11例，女性 5 例と男性に多い傾向がみられた。ま た，半数の 8 例が肺結核の治療中に発症している.

本疾患の臨床経過は多彩であるが，急性腹症として 発症するのは稀で，一般には全身俋急感が長期におよ び，精查でも診断に難渋し，その後腹部腫瘤として発 見されることが多いと報告されている2).急性腹症と して発症した本疾患の報告は本症例を含め 5 例であっ た(表 2 )。全例に腹痛，4例に発熱を認めるが，特徴 的なことは 1 例を除き末梢血中の白血球数の上昇が軽 度であることである。しかし，確定診断がつかないま まに全例開腹術を行い，結核性腸間膜りンパ節炎の診 断に至っている。これは本疾患の診断方法が末だ確立 していないからである. 津久井ららは，腸間膜リンパ節 の腫大は超音波検査で描出可能な症例が多く，その特 徵としては hypoechoic mass が腸間膜に一致して多 数認められ，非侵襲的で有用であると述べている。一 方，井上ら ${ }^{21}$ は，超音波検查では周囲臓器との位固関倸 や腸管ガスなどにより，常に正確な情報が得られると は限らず, CT 検査を奨めている。本症例は術前に超音 波検査を施行したが，腸管ガスが多く鮮明な画像が得 られず，腸間膜りンパ節腫大の診断はできなかった。 Hulnick ら ${ }^{6}$ は, CT による腹部のリンパ節結核の特徵 として，(1)脺周囲や腸間膜でのリンパ節腫大，(2)大き な結節内の中央に低濃度領域を認める, (3)腹水が比較 的高浱度で多房性に貯留する, (4)腹膜の造影効果を伴 い，腸間膜や大網の軟部組織の変化を認める，(5)消化 管内の病巣に接して腫大したリンパ節が存在する，の

表 2 急性腹症として発症した結核性腸間膜リンパ節炎

\begin{tabular}{|c|c|c|c|c|c|c|c|c|c|}
\hline No & 報告者 & 年度 & 年齢 & - 性 & 主訴 & $\begin{array}{l}\text { 白血球数 } \\
\left(/ \mathrm{mm}^{3}\right)\end{array}$ & $\underset{(\mathrm{mm} / \mathrm{hr})}{\text { 血 }}$ & ツ 反 & 術前診断 \\
\hline 1 & 黒川? & 1986 & & 男 & $\begin{array}{l}\text { 発熱 } \\
\text { 腹痛 }\end{array}$ & 8,300 & 5 & 記截なし & 腹腔内膿癗 \\
\hline 2 & 柿原" & 1987 & 27 & 男 & $\begin{array}{l}\text { 発勢 } \\
\text { 腹痛 }\end{array}$ & 20,700 & 32 & 弱陽性 & 恐室炎 \\
\hline 3 & 津久井 ${ }^{5 \prime}$ & 1988 & 11 & 男 & $\begin{array}{l}\text { 登熱 } \\
\text { 腹痛 } \\
\text { 下痢 }\end{array}$ & 7,600 & 記载なし & 強陽性 & $\begin{array}{l}\text { 腸間膜 } \\
\text { リンバ節炎 }\end{array}$ \\
\hline 4 & 菊池") & 1991 & 24 & 女 & $\begin{array}{l}\text { 腹痛 } \\
\text { 血便 }\end{array}$ & 8,600 & 記载なし & 陽 性 & 腹腔内腫瘤 \\
\hline 5 & 自験例 & 1995 & 28 & 女 & $\begin{array}{l}\text { 発熱 } \\
\text { 復痛 }\end{array}$ & 6,400 & 29 & 弱陽性 & 急性虫垂炎 \\
\hline
\end{tabular}


5 点を挙げている，本症例は，急性虫垂炎の疑いで緊 急入院した28歳の若い女性であり，しかも，入院後発 熱と腹痛が増強して緊急手術となったため, 術前に CT 検查は施行していない。

本疾患の報告例はいまだ少数のため確立されたアプ ローチの仕方や診断法がないのが現状であるが，以下 の 3 点が重要であると思われた. (1)急性虫垂炎の疑い のある症例で, 手術が必要であると思われる程の強い 炎症症状を呈しながら, 白血球数の増加が中等度以下 の症例は本症を疑う。(2)急性虫垂炎の術前診断で手術 を施行し，その鑑別診断として頻度の高い腸間膜リン パ節炎に遭遇した場合，虫垂切除のみに留まらず，積 極的にリンパ節生検を行い, 病理組織学的に確認する 必要がある。(3)本症例を含め報告例を検討してみると， 結核と確定診断がつくまでの術後約 1 週間，一般的な 抗生物質投与でも急性炎症の症状は軽快している。す なわち,この期間は必ずしも抗結核薬の必要性はなく， 通常の術後に対する化学療法を行い，その後に根治性 を考え抗結核薬を投与しても良いと思われた。

\section{結 語}

急性腹症として発症した結核性腸間膜リンパ節炎の 1 症例を経験したので報告した。

稿を終えるにあたり,御指導, 御校閱を賜りました香川医 科大学第 1 外科学教室前田 壁教授, 高知医科大学第 1 病 理学教室原弘教授に心から感謝致します。

\section{文献}

1）山本哲郎：V 急性虫垂炎. 和田達雄 監修, 新外科 学大系, 小児外科VI, 第 30 巻 D, 中山書店, 東京, $1990, \mathrm{p} 33-44$

2）井上祐一, 金森頼和, 三浦直樹他：肺結核治療中に 腹部腫瘤にて発見された腸間膜りンパ節結核の1 例. 結核 $66: 543-550,1991$

3) Gilinsky NH, Marks IN, Kottler RE, et al : Abdominal tuberculosis. A 10-year review. S Afr Med J 64 : 849-857, 1983

4）佐藤三郎：診断困難であった腸間膜淋巴腺結核の 1 例. 医療 $7: 386-387,1953$

5）津久井優, 町村貴郎, 花上 仁他：超音波が急性虫 垂炎との鑑別に有用であり，且つ臨床経過より結 核を強く示唆された急性腸間膜リンパ節炎の 1 例. 神奈川医会誌 $15: 143,1988$

6) Hulnick DH, Megibow AJ, Naidich DP, et al : Abdominal tuberculosis. CT evaluation. Radiology $157: 199-204,1985$

7）黑川善栄, 桐岡智二, 神谷順一他：腸間膜リンパ節 結核の破裂による汎発生腹膜炎の 1 例. 臨外 41 : 1589-1592, 1986

8）柿原昌弘,三上祐司，山本茂生他：上行結腸瘦を形 成した腸間膜結核性リンパ節炎の 1 例. 日内会誌 $76: 898,1987$

9）菊池嘉一郎，飯田修平：腹部腫場との鑑別が困難 であった腸間膜結核の 1 例。日消外会誌 24 ： 2065一2069, 1991

\title{
A CASE OF TUBERCULOUS MESENTERIC LYMPHADENITIS PRESENTING DIFFICULTY IN DIFFERENTIATION FROM ACUTE APPENDICITIS
}

\author{
Kotaro MATSUSHITA, Muneo KITAMURA and Sakuji ASHIHARA \\ Department of Surgery, Hosogi Hospital
}

In recent years tuberculous mesenteric lymphadenitis presenting with an acute abdomen is rare that sometimes offers difficulty in diagnosis. We experienced a patient with tuberculous mesenteric lymphadenitis which was diagnosed at laparotomy and by postoperative histologic examination. This case also presented difficulty in differential diagnosis from acute appendicitis. A 28-year-old woman was admitted to the hospital because of a fever and right lower abdominal pain. Acute appendicitis was suspected from physical findings of the abdomen. Blood chemical examination revealed white blood cell count of 6,400 . Because of persistent fever and abdominal pain, surgery was performed on the second hospital day. Surgical findings included sligh ascites and lymph node swelling of various sizes at the ileocecal mesenterium. The patient was diagnosed pathohistologically as tuberculous mesenteric lymphadenitis. Yersinia enterocolitica is a common pathogen of mesenteric lymphadenitis and Mycobacteriumtuberculosis are rarely reported in the literature. Early diagnosis and treatment of this disease are important, because excellent chemotherapy is available for tuberculosis. 